\title{
Dilemmas in Teachers' Use of Digital Technologies in Everyday School Practice
}

\author{
Sadaf Salavati \\ Department of Informatics, Linnaeus University, sadaf.salavati@1nu.se
}

\begin{abstract}
Major investments in Sweden have equipped schools with digital technologies. However, the digital technologies are, reportedly, not being used to support everyday teaching and learning practices. Rather, the digital technologies are mainly used as administrative tools. In order to enable teachers to adopt and use digital technologies, it is crucial to understand their worldviews and their everyday practice, as well as external influences and underlying perspectives.

In response, this paper discusses dilemmas associated with teachers' everyday practice using digital technologies. The research methodologies included a Focused Ethnographic approach complemented by Soft Systems Methodology, especially Rich Pictures. Results provide rich context for appreciating the complex dilemmas experienced by four teachers, two school leaders, three representatives from the Department of Education and the head of the municipal IT unit, who together constituted the informants for this research.
\end{abstract}

Key words: compulsory school education, focused ethnography, Rich Picture, Soft Systems Methodology, teachers

(C) 2015 Sadaf Salavati. This is an Open Access article distributed under the terms of the Creative Commons Attribution-NonCommercial 4.0 International License (http://creativecommons.org/ licenses/by-nc/4.0/), permitting all non-commercial use, distribution, and reproduction in any medium, provided the original work is properly cited.

http://dx.doi.org/10.15626/dirc.2015.16 


\section{Introduction and Background}

The reality of education cannot be found in either books or laboratories, or even in classrooms where teaching and learning takes place (Dewey, 1929). Rather, the reality of education can only be found in the thoughts and minds of those engaged in the educational practices. A number of researchers argue that teachers' beliefs and perceptions about their professional role need to be considered when advancing adoption of educational innovations (e.g., Tondeur et al., 2008; Geertsema, 2014). Tondeur et al. (2008) argue that teachers most easily accept innovations that correspond with their personal thoughts and ideas about teaching and learning. In this spirit, this paper explores a contemporary dilemma in Swedish classrooms where technologies are not used to their full potential (Skolinspektionen, 2012; Skolverket, 2013; Skolverket, 2016). Reports from the European Commission, the Swedish government and the Swedish National Agency for Education similarly acknowledge low use of digital technology in school education (Näringsdepartementet, 2011; SFS, 2010:800; Skolverket, 2011; Skolverket, 2016), despite the wide and ubiquitous existence of digital technologies (Bradley, 2006; Digitaliseringskommissionen, ${ }^{1} 2015$ ).

The importance of digital technology in education has also been addressed by scholars (e.g., Dillenbourg, Järvelä and Fischer, 2009; Grönlund, 2014; Laurillard, 2012; Scardamalia, et al., 2010), arguing for technology integration in teaching and learning in order to prepare youngsters for the 21 st century knowledge society. Other scholars (e.g., Bates, 2015; Laurillard, 2012) note that digital technologies introduced into classrooms were not initially developed for educational purposes. Oftentimes, digital technologies are placed in classrooms in the hope that teachers will use the technology eventually to marginally improve teaching, despite an absence of technology enhanced pedagogical models (Bates, 2015; Christiansen, Horn and Johnson, 2008; Grönlund, 2014; OECD, 2010; Papert and Solomon, 1972). Grönlund (2014) argues that the digital technologies dilemma in school education is less about access to equipment and more about to the pedagogics and learning perspectives.

Various scholars (e.g., Gibson, 2001; Sharples, Taylor and Vavoula, 2007; Bates, 2015) argue that implementation and use of digital technologies changes relationships in the classrooms. They say it changes the teachers' role, and it also influence teachers' relationships to their students and perspectives on their professional roles. Gibson (2001) explains that teachers that use digital technologies with confidence tend to feel more professional since they can enhance student learning rather than merely transfer knowledge. Gibson (2001) further argues that use of digital technologies impacts teachers' beliefs and mindsets, whereby teachers who mainly use variations of traditional pedagogy and didactics tend to question their beliefs. In order for teaching to become successful, Mishra and Koehler

${ }^{1}$ The Swedish Digital Commission 
(2008) argue that three knowledge bases, (1) Pedagogy, (2) Content, and (3) Technology, need to be present in balanced dynamic interaction. The relationships among and integration of these knowledge domains create variations, and, if out of balance, produce dilemmas when integrating digital technologies in education (Mishra and Koehler, 2008). This is made all the more complex because technologies do not merely enable a single pedagogical orientation, but rather support wide variation of approaches to teaching and learning (Bates, 2015).

Therefore, educational practice is highly complex. It consists of several actors, roles, entities, and relationships with varying power and influence. Within the complex context of the problematic situation for adoption and use of digital technologies (Salavati, 2013; Gaffney, 2010), teachers ultimately decide to adopt - or not adopt - digital technology to enhance the learning environment. As Griffin (2003) observes, teachers determine if and how digital technology will be useful and effective. Given the dynamically changing educational landscape, Grönlund (2014) recommends investigation and exploration of current learning and teaching processes in schools. He asks: what do teachers do differently and why are these ways better or are not better? (Grönlund, 2014, p. 19).

Gaffney (2010) describes the adoption and use of digital technology by teachers as consisting of two dimensions: understanding teachers' multi-dimensional profession and understanding the external influences. The teachers' multidimensional work nature includes e.g. personality, experiences, professional knowledge and specific contexts as well as the schools' desired learning and teaching culture. The external influences Gaffney (2010) describe includes availability, suitability and costs of the technology; technical expertise and timely technical support; appropriate in-service and organizational development; and leadership on school and political level. Gaffney (2010) further argues that the nature of teachers' local situations for adopting and using digital technologies is complex, dynamic and contextual - i.e., "wicked". This causes dilemmas which need to be better understood in order to realize in the potential of digital technologies in everyday teaching and learning practice. Therefore, the aim of this paper is to identify and explore dilemmas in teachers' complex everyday practice using digital technologies. The aim will be guided by discussing the following research issue:

- What dilemmas can be identified in the complexity of teachers' use of technology in their everyday work practices?

Following this Introduction and Background, the next section presents the Research Methodology and Design. The third section describes the Empirical Setting and Data Collection. A concluding fourth section presents the Research Results and Discussion, including concluding observations related to the conference theme of dilemmas. 


\section{Research Methodology and Design}

This paper reports results from Salavati's (2016) doctoral research most relevant to illuminating teachers' dilemmas. Research methodology included Focused Ethnography, complimented by Soft Systems Methodology (SSM), specifically the Rich Picture technique.

Ethnographic research methods were selected to provide richly nuanced data, with the aim to "appreciate what it means to be human in particular social and cultural contexts" (Madden, 2013, p. 17). In this instance, an ethnographic approach permitted deep understanding of the everyday practices of teachers and their use of digital technologies. Focused Ethnography, also known as a shortterm approach (Knoblauch, 2005; Pink \& Morgan, 2013), was used to gather large amount of data within an shorter, however more intense periods of field studies (Knoblauch, 2005; Pink and Morgan, 2013).

Methods used for data collection included observations and interviews. When conducting observations, the researcher followed two approaches; keep her true role as researcher hidden from most people and known only to certain "gatekeepers"; however, for some situations the researcher's role and identity was fully disclosed and allowed the researcher to take on a shadowing approach. In combination, these complementary approaches allowed the researcher to observe without affecting the natural setting and thereby witness and study the normal life and intimate details of interest (Pole \& Morrisson, 2003).

Soft Systems Methodology, or SSM (e.g., Checkland, 1999), was used to gain a more holistic understanding, as well as to organize and structure large data sets for analysis, interpretation, and presentation. The Rich Picture technique (Checkland \& Poulter, 2006) is used as the first phase, finding out, of Soft Systems Methodology. Rich Pictures aim to illustrate and represent a problematic situation without imposing unnecessary structure or excluding elements or terms. Using the Rich Picture technique, it is possible to show the complexity of a situation including, but not limited to, viewpoints, ongoing processes, known and potentials issues (Checkland \& Poulter, 2006).

\section{Empirical Setting and Data Collection}

The empirical settings consisted of two compulsory schools located in the south of Sweden. In total, four teachers were observed and interviewed. The teachers were observed for some full days, in which the researcher 'shadowed' them as they prepared classes, taught in classrooms, conversed with colleagues and students, interacted during coffee breaks, etc. Two interviews, one addressing philosophies of teaching and the other related to perception and use of digital technologies, were also conducted with each teacher, closely related in time with the observations. Each interview lasted for approximately 60 minutes and was recorded. All 
collected empirical material was transcribed verbatim and sent to each teacher for approval.

Additionally, school leaders from each of the schools were interviewed, as well as three representatives from the Department of Education at the municipality and the head of the municipal IT unit. Each 60 minute interviews with school leaders and municipality representatives was recorded and transcribed verbatim. Transcriptions were sent to each respondent for approval.

\section{Research Results and Discussion}

The result of the most relevant empirical data is illustrated in one highly detailed Rich Picture (Figure 1). The top left corner of the Rich Picture below represents how the CIO of the IT unit view and describe the situation. The representatives of the Department of Education are presented below the CIO of the IT unit and the lower left corner illustrates the school leaders' perspective on teachers' everyday practice. The circle in the middle of the figure represents the four teachers' viewpoints. For detailed descriptions and enlarged illustrations of specific parts of the Rich Picture, see Salavati (2016).

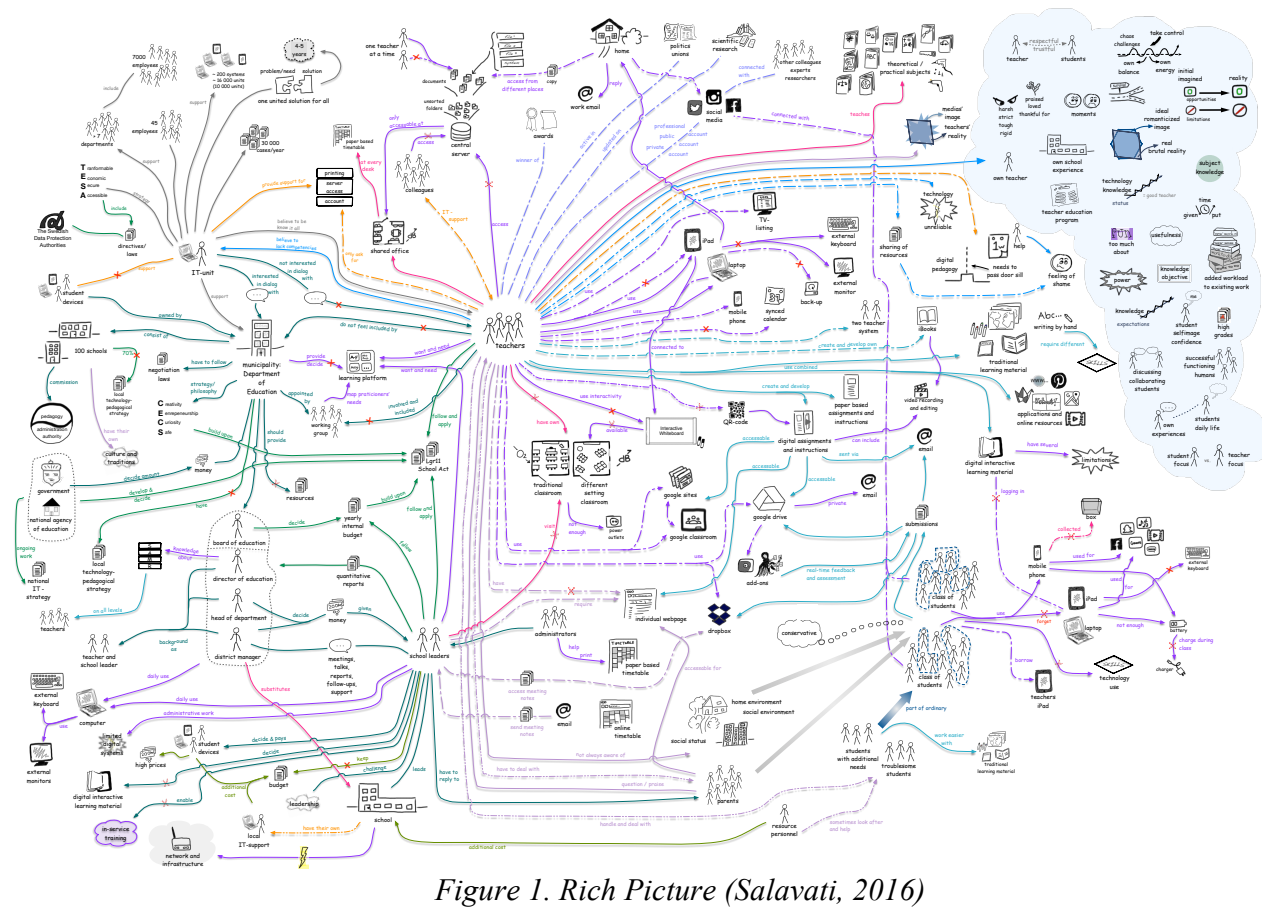

The middle and right sides of the figure represent the everyday practice of the teachers' use of digital technologies in everyday practices, and the blue area in the top right corner represents the teachers' philosophy and mindsets about their role 
as teachers. The philosophies, beliefs and values are based on the teachers' backgrounds and experiences and their varying social and personal contexts, as well as how teachers think about their professional roles as teachers and how their beliefs about their students' learning (Korn, 2003; Salavati, 2016). These worldviews and philosophies influence and affect the everyday practice and how the teachers use the digital technologies, resulting in a complex situation consisting of several dilemmas discussed below.

Teachers in this research expressed and demonstrated an interest and will to use digital technologies in their everyday practice. However, they experienced several obstacles and challenges related to schools' and classrooms' digital technologies' implementations. Amongst the most significant circumstances was teachers' decision making processes concerning, e.g., what technologies to use and how, as well as the effects on their individual teaching philosophies and pedagogical approaches. Such obstacles and challenges causes a collective dilemma concerning will, interest, and enablement to use digital technologies in everyday practices.

The pressure on the school leaders and the pressure from school leaders on teachers to use the digital technologies in their teaching is another clash, and hence, a critical dilemma. This multifaceted dilemma includes that some teachers, as revealed in this research, when under pressure to use the digital technology and to adapt their teaching pedagogy and practice, will exhibit reluctance towards the use of the digital technology. This results in a challenging position for the school leaders who need to ensure digital technology is used in the everyday teaching and learning practices while at the same time ensure that teachers freedom to make pedagogical choices.

To further complicate the situation, insufficient technology resources is also causing an dilemma. For instance, as illustrated in the bottom left corner of Figure 1 , there is limited network and infrastructure to support teachers' and students' needs. In addition, on a day-to-day basis, teachers oftentimes lack access to external computer monitors and keyboards, as illustrated in the higher middle right side of the figure. So, although a number of teachers reported high ambitions to integrate and use digital technologies, the lack of technology devices in combination with the lack of pedagogical direction limited integration into the classroom.

These local budget, guideline and policy constraints were further complicated by decision makers at the Department of Education. Their mandate required that they follow national policies and steering documents (illustrated in the lower left side of Figure 1), ensure and enable school leaders to govern and take care of their school in accordance to the freedom they are entitled to as school leaders, and follow recommendations and solutions provided by the municipal IT department. The dilemma in this situation lies in finding a balance between these three, often contradicting, directives, which affects and influences teachers and their everyday practice using digital technologies. 
Additionally, although the Department of Education decision makers are expected to take decisions based on the everyday reality of teachers and students, teachers are not being included in these decisions. Therefore, the decisions on what technologies to use and how to use them is many times not in line with the needs and wishes of the teachers. Research findings indicate that the teachers feel that they are not heard by the decision makers who, they say, do not have the full picture of day-to-day practice, while the decision makers believe they do understand.

This clash of understanding between classroom teachers and decision makers is further complicated by the variation in teachers' professional philosophies, teaching styles and personal preferences, which the Chief Information Officer and her/his IT unit need to consider. As illustrated in the higher left side of the Figure, the CIO prefers to have a dialog with the Department of Education decision makers rather than with the teachers. The challenge and dilemma, in this context, lies in the limited insight of teachers' everyday practice and the impossibility to gain holistic understanding of all needs and wishes based on individual teachers' different and contradictory worldviews. The CIO of the IT-unit, together with decision makers and representatives from the Department of Education are obligated to follow national laws and policies which are not always in line with the needs of the teachers and school leaders. The representatives of the Department of Education and the CIO are aware that teachers and school leaders use digital technologies not supported by the laws and regulations, but the representatives of the Department of Education and the CIO have to comply since they yet have not managed to find alternatives which are in line with the teachers' and school leaders' needs and wishes.

The problematical situation is further challenged by the availability, level and content of in-service training. Current in-service training is experienced by some teachers as too difficult level, by others as appropriate and by yet others as too basic. This variation in perceptions reflects different teachers' needs, knowledge and skills, as exemplified in the lower left corner of Figure 1. The dashed cross illustrates that some school leaders do not provide any in-service training but rather encourage information and knowledge sharing within the schools and among the teachers rather than through an external provider.

As the preceding discussion indicates, digital technology adoption and integration requires addressing the various issues related to digital technologies usage, pedagogics, and training, which influence and affect everyday practices. The overarching dilemma concerns how to acknowledge and balance variation in philosophies, worldviews and needs while considering the teachers' and school leaders' freedom to plan and deliver education. Addressing this dilemma is vital to enabling enhancement of everyday teaching and learning practices using digital technologies. 


\section{Conclusions}

This paper focused on selected outcomes of research on the use of digital technologies in everyday school practice, as determined through observations and interviews with teachers, school leaders and representatives from the municipal Department of Education and the CIO of the IT-unit. Results identify multiple dilemmas in teachers' use of digital technologies in everyday teaching practices in terms of the teachers' multi-dimensional profession as well as external influences (cp. Gaffney, 2010). Dilemmas identified in this paper included: teachers' different interests and will of using digital technologies; the pressure to use digital technologies; the freedom of choices in terms of teaching for the teachers and managing the school for the school leaders; the decision making of the representatives of Department of Education on municipality level; understanding of all varying needs and wishes and thereafter providing needed services and support by the $\mathrm{CIO}$ and the municipal following national policies; etc.

Because teaching practices are complex, dynamic and contextual, the dilemmas are complex, made all the more so by the numbers of actors and stakeholders who have multiple and varying worldviews about education and, more specifically, about use of digital technologies in everyday practices.

In order to more fully enable everyday practice where digital technologies are a natural support to teaching and learning, these issues need further investigation; ; a deeper understanding of the varying actors' worldviews and a bridge in understanding of other actors', stakeholders' and practitioners' worldview and perception of the everyday teaching practices.

\section{Acknowledgements}

The author would like to thank Anita Mirijamdotter and Christina Mörtberg at Linnaeus University for all their guidance, help and support. A special thank you to all teachers, school leaders and representatives from the municipality for allowing me to enter your worlds, making this research possible. Thank you reviewers for the helpful comments on earlier drafts of this paper. Thank you, Mary Somerville, for the editing.

\section{References}

Bates, A.W., 2015. Teaching in a Digital Age: Guidelines for design teaching and learning. Ontario: BCcampus. [Online] Available at:

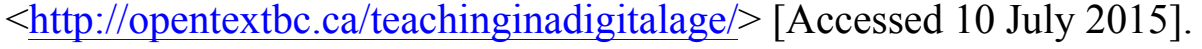

Bradley, G., 2006. Social Informatics - From Theory to Actions for the Good Society. In: T. Berleur, M. I. Numinen, \& J. Impagliazzo, ed. Remembrance of Rob Kling. Boston: Springer. pp.383-394. 
Checkland, P., 1999. Systems Thinking, Systems Practice: Includes a 30 year Retrospective. Chichester: John Wiley \& Sons.

Checkland, P. and Poulter, J., 2006. Learning for Action: A short Defibitive Account of Soft Systems Methodology and its use for Practitioners, Teachers and Students. Chichester: Johen Wiley \& Sons.

Checkland, P. and Winter, M., 2006. Process and Content: Two ways of Using SSM. The Journal of the Operational Research Society, 57(12), pp.14351441.

Christensen, M.C., Horn B.M. and Johnson, W.C., 2008. Disturbing Class: How Disruptive Innovation Will Change the Way the World Learns. USA: McGraw-Hill.

Dewey, J., 1929. The Sources of a Science of Education, The Kappa Delta Pi Lecture Series. New York: Horace Liveright.

Dillenbourg, P., Järvelä, S. and Fischer, F., 2009. The evolution of research on computer-supported collaborative learning: from design to orchestration. In: N. Balacheff, S. Ludvigsen, T. de Jong, T.A. Lazonder \& S. Barnes, ed. Technology-enhanced learning: Principles and products. Netherlands: Springer. pp. 3-19.

Gaffney, M., 2010. Enhancing Teachers' Take-up of Digital Content: Factors and Design Principles in Technology Adoption, Education Services Australia, [Online] Available at: $<$ http://www.ndlrn.edu.au/verve/ resources/ Enhancing_Teacher_Takeup_of_Digital_Content_Report.PDF $>$ [Accessed 23 January 2016].

Geertsema, J., 2014. Technology and the role of the teacher. CDTL Brief, 17(1), pp. 2-3.

Gibson, I. W., 2001. At the intersection of technology and pedagogy: considering styles of learning and teaching. Journal of Information Technology for Teacher Education. 10(1-2), pp. 37-61.

Griffin, J. D., 2003. Technology in the Teaching of Neuroscience: Enhanced Student Learning. Advances in Psychology Education, 27(3), pp.146-155.

Grönlund, Å., 2014. Att förändra skolan med teknik: Bortom "En dator per elev", Örebro: Örebro University, [Online] Available at: $<$ http://www.divaportal.org/smash/get/diva2:706366/FULLTEXT01.pdf $>$ [Accessed 20 August 2014].

Korn, J.H., 2003. Writing a philosophy of teaching. In W. Buskit, V.W. Hevern, B.K Saville \& B.K Zinn, ed. Essays from excellence in teaching, Vol. 3. Society for the teaching of psychology. (pp 46-49). [Online], Available at: $<$ http://teachpsych.lemoyne.edu/teachpsych/eit/eit2003/index.html $>$ [Accessed 05 January 2015].

Knoblauch, H., 2005. Focused Ethnography [30 paragraphs]. Forum Qualitative Sozialforschung / Forum: Qualitative Social Research, 6(3). 
Laruillard, D., 2012. Teaching as a Design Science: Building Pedagogical Patterns for Learning and Technology, New York: Routledge.

Madden, R., 2013. Being Ethnographic: A Guide to the Theory and Practice of Ethnography. Sage Publications Ltd.

Mishra, P. and Koehler, M., 2008. Introducing Technological Pedagogical Content Knowledge. Annual Meeting of the American Education Research Association, New York City, March 24-28, 2008.

Näringsdepartimentet, 2011. ICT for Everyone - A Digital Agenda for Sweden, 2011, (N2011.19) Stockholm: Ministry of Enterprise, Energy and Communications, [Online] Available at: <http://www.regeringen.se/

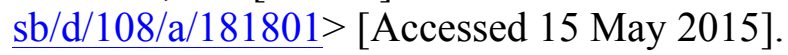

Organisation for Economic Co-operation and Development (OECD), 2010. Inspired by Technology, Driven by Pedagogy: A Systemic Approach to Technology-Based School Innovations. Paris: OECD Publishing.

Papert, S. and Solomon, C., 1971. Twenty Things To Do With A Computer, A. I. Laboratory, Massachusetts Institute of Technology, [Online] Available at: $<$ http://hdl.handle.net/1721.1/5836> [Accessed 19 May 2015].

Pink, S. and Morgan, J., 2013. Short-term Ethnography: Intense Routes to Knowing. Symbolic Interaction, 36(3), pp. 352-361.

Pole, C. and Morrison, M., 2003. Ethnography for Education. Berkshire: Open University Press.

Roper, J. M. and Shapira, J., 2000. Ethnography in Nursing Research. Thousand Oaks, Calif: Sage Publications.

Salavati, S., 2013. Novel Use of Mobile and Ubiquitous Technologies in Everyday Teaching and Learning Practices: A Complex Picture. Licentiate, Linnaeus University Faculty of Technology, Department of Informatics. Växjö: Linnaeus University Press

Salavati, S., 2016. Use of Digital Technologies in Education: The Complexity of Teachers Everyday Practice. Ph.D. Linnaeus University

Scardamalia M., Bransfordm J., Kozmam B. and Quellmalzm E., 2010. New assessments and environments for knowledge builders. The University of Melbourne

SFS 2010:800. Skollag. Stockholm: Utbildningsdepartementet, [Online], Available $\quad$ at: $\quad<$ http://www.riksdagen.se/sv/Dokument-Lagar/Lagar/ Svenskforfattningssamling/Skollag-2010800_sfs-2010-800/\#K10> $\quad[$ Accessed 24 July 2015].

Sharples, M., Taylor, J., and Vavoula, G., 2007. A theory of learning for the mobile age. In: R. Andrews, and C. Haythornthwaite, ed. The Sage handbook of e-learning research. London: Sage Publications Ltd. pp.221-247.

Skolinspektionen, 2012. Satsningarna på IT används inte $i$ skolornas undervisning. (Dnr 40-2011:2928), [Online] Available at: 
$<$ http://www.skolinspektionen.se/Documents/Kvalitetsgranskning/it/pm-itiundervisningen.pdf $>$ [Accessed 15 May 2015].

Skolverket, 2011. Curriculum for the compulsory school system, the preschool class and the leisure-time centre 2011 (Lgr11). Stockholm: Skolverket, [Online] Available at: <http://www.skolverket.se/publikationer?id=2687> [Accessed 17 May 2015].

Skolverket, 2013. It-användning och it-kompetens i skolan. [Online] Available at: $<$ http://www.skolverket.se/publikationer?id=3005 $>$ [Accessed 17 May 2015].

Skolverket, 2016. IT-användning och IT-kompetens $i$ skolan. Skolverkets ITuppföljning 2015. (Dnr: 2015:00067), [Online] Available at: $<$ http://www.skolverket.se/publikationer?id=3005 $>$ [Accessed 11 April 2016].

Tondeur, J., Hermans, R., van Braak, J. and Valcke, M., 2008. Exploring the link between teachers' educational belief and profiles and different types of computer use in the classroom. Computers in human Behavior, 24, pp.25412553. 